\title{
Representation of Illegitimate Affairs: A Study of Chaman Nahal's The Gandhi Quartet
}

Ms. Sudha Devi Shanmugam, Ph. D Research Scholar, Department of English, Thiruvalluvar University, Vellore, Tamilnadu, India

Dr. Kannadhasan Manimurasu, Assistant Professor, Department of English, Thiruvalluvar University, Vellore, Tamilnadu, India

\begin{abstract}
:
In Chaman Nahal's The Gandhi Quartet. illegal relationships assume a crucial part in the fictionalization of numerous authentic and political occasions of Indian history from 1915 to 1952.They are utilized predominantly to fill in as an artistic method to lessen the characters to simple humans by depicting them as being not able to oppose the enticements of their lustful cravings, along these lines keeping them from being romanticized and causing them to show up as standard individuals, not as demi-divine beings. Yet, for their unlawful relationships, every one of the noticeable characters, particularly Gandhi's adherents, specifically Sunil, Kusum, Raja Vishal Chand, Vikram and Rahena would have showed up so great. Another reason that illegal issues serve in the epic novel is the impression of socially inadmissible types of man-lady relationship like elopement, free love, inbreeding and live-in winning both in Indian culture just as in British society during the hour of Indian opportunity development.
\end{abstract}

Keywords: Fictionalization, Romanticized, Cravings, Unlawful, Socially, Elopement.

Chaman Nahal's perfect work of art, The Gandhi Quartet, including four volumes. The Crown and the Loincloth, The Salt of Life, The Triumph of the Tricolor and Azadi are maybe the best Indian fiction in English which manages Indian opportunity development and paints a complete, practical and unsparing image of Gandhi's character. Sadly, the magnificence of the previously mentioned topics has predominated the subject of man-lady relationship, which to be sure assumes a critical part in the fictionalization of numerous recorded and political occasions of Indian history from 1915 to 1952. Man-lady relationship depicted in the novel might be ordered into two sorts: the one that exists inside the limits of marriage and the other that falls past the wedlock. The last mentioned, which is, by normal assent, alluded to as unlawful relationship or illegal relationship, really offsets the previous as far as the space it possesses in 
the novel just as the complex purposes it serves to make the story of Indian opportunity battle, with Gandhi as its hero, a great fiction. The ulterior thought process behind the work of various illegal issues in the novel isn't really to brighten up the political occasions of public significance, however it is predominantly to try not to admire the noticeable anecdotal characters and loan them a reasonable shade by ascribing to them the most well-known and simultaneously the greatest human coming up short that is, the failure to oppose the impulse to taste the prohibited organic product. Significant characters, particularly the most unwavering votaries of Mahatma Gandhi, specifically, Sunil, Kusum, Raja Vishal Chand, Rahena and Vikram. are, hence, made to get sucked into unlawful undertakings. Indeed, even Mahatma Gandhi, however he isn't presented to any illegal undertaking, isn't totally saved; he can't yet see his better half's body without want even subsequent to having taken the pledge of chastity in 1906. In such manner, Ambuj Sharma says, "Mohandas adored Kasturbai's excellence even in the wake of taking the promise of abstinence."

Gandhi likewise neglects to stay oblivious to Kusum's magnificence or freezing when they walk intently by the waterway one morning in The Salt of Life. With regards to the directions of Gandhi, Sunil, the main person of The Crown and the Loincloth forfeits all that he has on the special stepped area of turning into a Congress volunteer; he neglects his work as an administration secondary teacher and a tranquil and secure life at his dad's haveli in Ajitha, turns into the primary individual to set up a Khadibhandar in Ajitha, goes to Rohru, a town in Simla Hills, to help the estate laborers took advantage of by the British and lumber traders and broadens his visit there independently to help the untouchables called Doms joins the standard of life-he even utilizes Chandru, a Dom, as his cook, causing everyone a deep sense of embarrassment. In any case, for every one of his forfeits, his extra-conjugal undertakings with two ladies, Rahena and Priti, corrupt his picture of being an optimal devotee of Gandhi.

The two issues are entirely against one another in that Sunil-Rahena issue includes no culmination of adoration though Sunil-Priti issue is totally founded on desire and it is a lot of an instance of a casual sexual encounter. Sunil and Rahena, Muzzafar's better half, experience passionate feelings for one another while cooperating as Khadi venders in Ajitha. However, their adoration develops further and more extreme as time passes, they don't enjoy actual closeness to keep their affection alive until the end of time. Rahena accepts that culminated love can just stop their enthusiasm or needing for one another. Rahena succeeds in persuading Sunil of her idea of 
never-ending love when he communicates his craving for the actual satisfaction of his enthusiasm with her. Rahena tells Sunil:

I wish we had had an affair and the matter would have ended, or would have dragged along for some time and then ended. But I truly love you and I believe you love me, too. It is a precious and the only way to keep it alive is by not coming too close physically. Consummated love is no better than an affair. (The Crown and the Loincloth: 291)

Rahena, by dint of her true and proficient work, ascends through the positions in the nearby Congress progressive system and turns into an agent of Ajith a khadi dealer at the AllIndia Khadi Bandhar Workers' Conference called by Manganlal Gandhi in Bombay, yet her undertaking with Sunil, however unconsummated, fills in as a dark detriment for her being a lady of substance. Despite what is generally expected, Sunil-Priti undertaking is set apart by culmination of desire. Sunil, notwithstanding being a hitched man, has no restraint when Priti, the spouse of three siblings Amin Chand, Labh Chand and Duni Chand, pays him an enthusiastic visit each night for a long time while remaining in Rohru. Shockingly, Sunil neither feels regretful nor is determined by any thought that their issue may become known to Priti's spouses, and Priti is too smart to even consider double-crossing whatever would stir their doubt.

Kusum, Nahal's most significant female person, and Raja Vishal Chand, the Maharaja of Lambini, figure among those adherents who are extremely near Gandhi, however they are knocked off their platform by their illegal issue. After the demise of her better half, Sunil, Kusum joins Gandhi's ashram at Sabarmati alongside her child, Vikram, as a badge of her support of the country. There she sparkles as a paragon of goodness, for around six years, by living like a cloister adherent; she keeps everybody at a manageable distance and carries out her responsibility truly and proficiently much to the appreciation of numerous ashramites and Gandhi. Raja Vishal Chand, one of the numerous who go to Gandhi's petitions, succumbs to Kusum and longs for her. At some point, whenever he gets an opportunity to converse with her, he figures out how to win her compassion by discussing his late mother, and the discussion takes them to the Maharaja's home close to the ashram. 
There he allures Kusum shockingly to her delight in light of the fact that, rather than getting her still, small voice pricked, she feels that her gentility has been at last reestablished. Communicating Kusum's satisfaction of gentility Chaman Nahal composes:

Rather it brought a relief, a restoration of femininity and dignity. The seed in her had sprouted again. The Raja Sahib might or might not marry her; it was inconsequential. She sat satiated in the worship that had been offered at her feet. (The Salt of Life: 86)

The information on Kusum's unlawful undertaking with Raja Vishal Chand and their choice to secure the bunch very before long shocks Gandhi and Vikram incalculable. Their relationship is officially solemnized in a basic wedding service performed by a cleric in the ashram's school compound, and it is gone to by Gandhi and Kasturbai. Of the relative multitude of adherents who sparkle in Gandhi's atmosphere, Vikram is the most brilliant for he neither achieves untimely affliction like his dad, Sunil, who kicked the bucket while saving the Prince of Wales by taking the projectile terminated at the Prince by Rakesh, a progressive, nor flames out like his mom, Kusum, who went into an unlawful undertaking with Raja Vishal Chand, after a brief and apparently encouraging shine in the ashram. In The Crown and the Loincloth, he stays in the shade of his dad as a little child, and after his dad's passing, he joins Gandhi's ashram at Sabarmati alongside his mom.

The second his mom chooses to wed Raja Vishal Chand and leave the ashram in The Salt of Life ends up being a watershed in his life; he rules against going to Lambini, his new dad's royal residence, and starts thinking about the ashram as his genuine house. He turns into a public saint at the young age of thirteen when he participates in the Dandi March and gets severely harmed because of lathi-charge by the police. His proclivity with Gandhi goes on in The Triumph of the Tricolor and at Gandhi's command he partakes, in a padyatra planned to extinguish the fire of common mobs set off by the arrangement of break government in 1946. In Azadi, after Gandhi's death, he chooses to remain in his Sevagram ashram and carry on the exercises began by the withdrew soul. Vikram is without a doubt the person who comes nearest to being called an optimal supporter of Gandhi. Be that as it may, his early undertaking with Julie, the girl of Colonel Michael Fogelson, means something negative for him. Vikram's first 
gathering with Julie traces all the way back to 1941 in Lambini during a mountaineering undertaking coordinated by Raja Vishal Chand to Gompah religious community. After the Maharaja's passing, they end up gathering again in Sialkot.

As the two of them live in Sialkot, Vikram regularly visits Julie's home and their associate step by step blooms into affection. Vikram is conflicted between his dependability to Gandhi's proclamations, as indicated by which he should stay abstinent, and his longing to perfect his affection with Julie. With regards to the crunch, Julie persuades Vikram that abstinence can be accomplished through guilty pleasure too. About Julie's hypothesis of chastity, the author expresses: "Came Julie Fogelson and she drooped into his arms and wailed. Relax, there can be abstinence through extravagance too, she murmured into his shuddering ears. How is that, he inquired. Furthermore, she showed him." (The Triumph of the Tricolor: 59)

Their actual closeness brings about Julie's pregnancy, however as her folks are particularly against Julie's undertaking with Vikram, they constrain her to go through an early termination. In the end, their adoration ends up being excessively solid for any snag or protests, and they get hitched with the favors of Julie's folks. Nahal depicts elopement, a crazy and barefaced type of illegal undertaking, as a social shame. Shyama experiences passionate feelings for Rakesh, her sibling Sunil's dear companion who later turns into a progressive. Rakesh visits her home consistently to meet his companion Sunil evidently, however his secret plan is to meet Shyama covertly.

Rakesh is against primitive rulers, among whom Shyama's dad Thakur Shanti Nath is one, and Rakesh's progressive thoughts very differentiation with Gandhi's thoughts of truth and peacefulness which Sunil appreciates and loves. Their philosophical contrasts slowly finish their fellowship and Shyama is compelled to pick either her Haveli and Rakesh. Being a blameless town young lady, she doesn't really hope for a world without Rakesh, though he desires her more than he cherishes her. She at last flees with Rakesh. Her elopement with Rakesh is viewed as a shame which harms the pride and honor of Thakur Shantinath's family to the joy of his adversary landowners and sick wishers. The circumstance is portrayed by Chaman Nahal in the accompanying word.

The news spread in no time and, as it pertained to a family as eminent as that of Thakur Shanti Nath, it left a mighty whiplash. His own 
tenants were sympathetic and showed grief. Yet the majority were happy, as they always are in the misfortunes of others. His rival zamindars felt the man was growing too tall and he needed a dressing down. (The Crown and the Loincloth: 114)

Nahal fastidiously investigates the sort of man-lady relationship that won among the progressives during the Indian opportunity battle. Illegal undertakings like elopement, free love and live-in relationship were extremely normal among the progressives, accordingly making a joke of social foundation called marriage. Sengupta and Charulata lived respectively, Rossie left her better half, a motor driver, and lived with her adored Hoshier Singh, Zahir ran off with Sultana, the little girl of a Lahore medico, Joseph lived with Dulara, a Hindu young lady and Darbara Singh's Salma was a previous whore of Hira Mandi. The youthful male progressives had the option to handily dazzle young ladies with lofty languages of Marxism which had not figured in their psyches. Progressives like Sengupta and Charulata were so lively, forceful and trying and consistently discussed retribution, yet at whatever point time allowed them, they had intercourse. They lived respectively and moved together starting with one spot then onto the next by making look like kin or cousins. The idea of their way of life and their work is depicted in an amusing way in the accompanying expressions of Nahal:

The girls abandoned all ties and ran away with the revolutionaries. Posing as sisters. Posing as cousins. Yet sleeping with them and talking of Marx. There was a mushroom of man-woman teams going around the country, generating political sedition during the day and sexual sedition during the night. They moved around in homespun white kurtas and pajamas or they wore Western style clothes. (The Crown and the Loincloth: 379)

Since progressives lead an exceptionally unreliable and erratic life, an enduring love affair is a far-off dream for them, and it has little worth when contrasted with their central goal to free India from the unfamiliar guideline. The author additionally shows that a miserable wedded life can situation an individual to have illegal illicit relationships with different ladies through the portrayal of Lala Dharam Das' relationship with his significant other, Viran Vati. On discovering 
that her mom is truly sick, Kusum goes to her parental home in Wazirabad after quite a while. She is stunned to find that her mom's ailment is set apart by incessant upheavals of outrage, and her dad is as a rule at the less than desirable finish of the fits. One late evening, Kusum ends up investigating her dad's room while attempting to change her wet garments, yet she can't accept the obvious reality when she sees her dad laying down with a lady.

When criticized by her little girl for doing a particularly wretched demonstration, Dharam says that his better half, Viran Vati has not permitted her significant other to draw close to her and denied him intimate freedoms from the absolute first evening of their marriage onwards, and out of disappointment he utilized power. Denied of intimate freedoms, he began looking for delight from different ladies. He tells her the sort of torment he has been exposed to by her mom: "Your mom has driven me to different ladies. From the principal day of our marriage, she has shown only antagonism, and outrage and harshness. (The Salt of Life: 236) Chaman Nahal discusses the presence of free love, inbreeding and genuine romance among the British.

The casual hookup between Cutlass, a British armed force official, and Ginger Barnes, the spouse of David Barnes, a British ICS official, at Udoka while a ball is occurring inside the congregation goes to show the pervasiveness of free love and unbridled conduct among the British. Be that as it may, the most corrupt man-lady relationship present in the British society is perverted relationship displayed by Percy Wand and Jennifer Wand. They are sibling and sister, yet the way wherein they blend with one another openly far surpasses the limits of kin relationship. Both the British and the Indians presume their relationship and make gossip. Yet, the talk fills in as an energizer to their relationship. Like darlings they are together more often than not. They likewise dance together and embrace each other in broad daylight. Their perverted conduct is portrayed strikingly by Chaman Nahal in the accompanying words:

The gossip about the two of them was not confined to the Indians alone. Their own folks spoke in similar innuendoes. Percy and Jennifer did nothing to curb the gossip. They rather felt stimulated by it. They danced together in the Lahore Club, embraced each other in full view of the elderly members of the club, and whenever occasion permitted travelled together on their trips - as the person near the bus stop said. The Salt of Life:153) 
The author doesn't preclude the commonness of depraved relationship in Indian culture. Lala Kanshi Ram's youngsters, Arun and Madhu however they don't go into any kind of unlawful relationship, they are excessively forthcoming with one another as though they were sweethearts. While expounding on Nahal's depiction of their relationship. The kind of transparency that is displayed corresponding to Madhu and Arun skirts practically on inbreeding which does viciousness to our feeling of appropriateness.

In "epilog" which is added to the 1993 release of Azadi, Chaman Nahal portrays socially unsatisfactory or remarkable man-lady connections winning among the British. Percy Wand and Jennifer Wand, regardless of being kin, live respectively in Australia. John Tree, a cleric, rather than driving a devout and ethically virtuous life, has a live-in relationship with his adored Carol Schnicke. Ginger separations her significant other David Barnes and lives with Brigadier Alan Cutlass. Lucy, the little girl of Ginger and David, doesn't cherish and isn't content with her progression father. She is determined to going to India to be with her dad, much against the wish of her mom. Unlawful relationships in Chaman Nahal's The Gandhi Quartet fill the double need of keeping the characters from being romanticized by making them incapable to oppose the allurement of licentious cravings and drawing out the different sorts of manwoman relationship outside the marry lock. Unlawful love affairs, therefore don't just enliven the narrative of Indian opportunity development in the epic Quartet yet assume a significant part in the fictionalization of the different political occasions relating to Indian opportunity battle. 


\section{References:}

Nahal Chaman: The Crown and the Loincloth, New Delhi, Allied Publishers (1993)

Nahal, ChamanAzadi, Arnold Heinemann, New Delhi: 1975, p. 93.

Nahal Chaman, The Salt of Life New Delhi, Allied, 1990.

Nahal Chaman,The Triumph of the Tricolour New Delhi, Allied, 1993.

Chandra, Bipan. Communalism: A Primer. New Delhi: Anamika Publishers, 2004. Print.

Engineer, Asghar Ali."Religious Fanaticism and Communalism.” Economic and Political Weekly 32.14 (1997): 701-704. Web.

Jain, Shashi Prabh. Gender revolution: a study of educated women. New Delhi: Radha Publications, 1999. 